\title{
The Social Welfare in the Succession of Omar Bin Al-Khattab (A Histological Approach)
}

\author{
Mohammad Ali Al-Rousan \\ Associate Professor of Modern History/ Irbid University College \\ Tareq Mohammad Al-Azzam \\ Associate Professor of Islamic History \\ Safwat Mahmoud Al-Rousan \\ Associate Professor of Sociology and Social Services \\ Al Balqa' Applied University - Irbid University College \\ P.O. Box 1239 \\ Jordan
}

\begin{abstract}
The study is an attempt to understand the reality of social welfare services during the succession of Omar Bin AlKhattab through the procedures and categories that were covered by this welfare. The study results found that Omar bin Al-Khattab was the most sensitive successor or Caliph toward the lived social reality and he was the first to be institutionally alert to the importance of providing the social welfare to those who deserve it and need it; in a systematical, institutional, and official manner to include the women, children, elderly, orphans, and the poor. The state has provided direct financial assistance and indirect services to these segments and categories, where special institutions were appointed to perform this task and the state, and the Caliph personally have adopted the caring and wellbeing of these groups. Therefore, the succession or Caliphate of Omar Bin Al-Khattab represents a country with an advanced institutions and a civilized society that recognizes the dignity and rights of human being.
\end{abstract}

Keywords: Caliph Omar Bin Al-Khattab, Social institutions, Social welfare services.

\section{Introduction}

Historically, the social welfare has been associated with the prevailing system in human societies and it's clear that societies have practiced its roles in social welfare; in different forms and ways that align with its civilized and cultural realities. Despite the fact that social welfare principles have been similar in the essence among the different nations based on the community duty concept toward the individual, but its philosophy today has been connected to the human rights idea and the incorporation between psychological and social needs, and the human dignity concept which in turn ensures a state of adaptation between the individuals or groups and their social environments, and give them the ability to perform their roles better. The state development is associated with its role in social welfare through its commitment to the social welfare of its citizens and its ability to deal with and face the social changes through the effectiveness of political forces that can control the economical, social, technological, and ideological life developments (Gooby, 1991). The modern institutional concept of social welfare sees it as a social system and a natural function that society practice to help individuals, groups, and communities on improving their social function, where the social welfare concept; in this broad meaning can be expanded to include all the things that humans need in their search for a happy life since every effort that can add something to a better social life may fall within the concept of social welfare (Attia \& Khalil, 2010). The speech about social welfare during the succession of Omar Bin Al-Khattab came from the abundance and richness of events that took place at this period of Islamic state history despite its shortness and according to most historical and social readings the succession or Caliphate of Omar Bin Al-Khattab occupied a milestone in the Muslim state formation, where Omar Bin Al-Khattab was the first to establish Al-Dawaween or registration which at that time expressed the state institutionalization.

\section{Study Problems}

Even though the conversation about the state of Omar Bin Al-Khattab goes for too long and branches in different ways, but the study through its problems and issues tried to understand the reality of social welfare in the interests and concerns of Omar Bin Al-Khattab and his state, in order to launch its main question that entitled: 
- What was the form of social welfare during the reign of caliph Omar Bin Al-Khattab?

- What are the segments that were targeted by this welfare?

\section{Study Objectives}

The study aims to highlight the beginnings of Islamic State's interest in the concept of social welfare, which according to the study is a form of civilized expression for the state's concern toward its citizens and the importance of paying attention to the problems of individuals and groups, and trying to find a solutions for it since the society with fewer problems consider the most advanced one in the political, social, and human sense or concept. Omar Bin Al-Khattab realized through his position as a caliph of Muslims that its one of his direct duty to take care of the state and citizens of different faiths based on Islam's understanding of humanity, taking into account that individuals have their human existence and needs; regardless of their differences. Omar Bin Al-Khattab also realized that as a caliph and a leader must provide everything that guarantees the lives of citizens, the respect for their humanity, and the preservation of their rights and stability. His caring and concern showed clearly in many areas where he was eager to communicate and connect with people in the various ways and methods, which may consider an advanced centralized form, where Omar summarized his method to deal with the social reality by saying "If I live hopefully "In Sha Allah" I will walk through the people or "Alrayyah" a full year, since I know that people have needs which will be cuts off without me, while their workers don't send it and introduce it to me, and they don't reach me" (Al-Tabari, 1977, C4, p. 201-202).

\section{Theoretical Framework}

\section{First: People's Interests and Social Justice:}

Omar Bin Al-Khattab adopted the centralize administration's style of government where he himself was following many of the issues and affairs that are important to the people in their immediate life, and Omar was inspecting the Muslims conditions and touring the city neighborhoods to ask about and check the situations of people, and provide the assistance and help to those who need it (Al-Tabari, 1977, c4, p. 204). Omar Bin Al-Khattab also showed his keenness about people's commitment to public morals where he toured the markets, watched the public morals, and punished those who made mistakes. In addition, he sought to safeguard the general rights of Muslims by preventing any attack on the roads that hindered the movement of people and their animals, and as an example he ordered Abu Sofian to destroy what he had built on the road (Ibn Shaba, 1996, c1, p. 363).

Omar Bin Al-Khattab also made it easy for people to worship and pray in the mosques, especially during the month of Ramadan and ordered to lightning it during this holy month (Ibn Assaker, 1996, c44, p. 280), and he was dedicated to spread the kindness and sympathy between the people and their governors, and to ensure the social justice among all people, and therefore if he heard or found that one of his workers doesn't visit the sick people or the weak people don't come to him took him out of the position (Abu Yusuf, 117).

Caliph Omar was a permanent advisor and a guardian for the people, where he ordered his workers not to attack people by humiliating them and not to prevent them from getting their rights, and not to risk them by wasting their lives. He also put emphasis on the equality between the opponents in the governors' councils and one time he wrote to Abu Obeida advising him to bring the weak opponent closer to his council to make his tongue speak and get rid of the fear. The Caliph Omar didn't stop there but he was devoted to meet the people; from all over the country during the hajj season and persuade them to present their grievances and complaints against his workers and governors, and if someone present a complaint for him he would get revenge from the worker or save himself by giving money to the complainant (Abu Yusuf, 115, 116, 117). Omar's care for the people wasn't limited to the above, but he sought to teach people and educate them about their religion to be true advocates of Islam, where he was in his sermon during the hajj season affirm that he had sent his governors and workers to teach people about their religion affairs (Tabari, 1977, c4, p. 204).

Among the areas of social welfare, Omar's care and concern about the health and physical matters by warning people of the dangerous eating habits where he warned them against the overeating due to its danger effects and its role in increasing their weights, and its impact on their health and on the performance of their worship and prayers, where he encouraged them to eat economically, stay away from wasting food, and warned them from listening to the lust of soul on food by saying: "Its enough of human to waste food by eating anything he desire" (Ibn Abby Al-Dunya, 1986, c2, p.311, 306). Omar was also committed to prevent the spread of infectious diseases among people, where he ordered the holders of infectious diseases to stay in their homes and not to go out to prevent them from transferring the disease to others (Malek Bin Anas, 1985, c1, p. 424) where Omar Bin Al-Khattab ordered to give a group of leprous Christians in Al-Sham from the charity money and pay for their food in order to stay home and not have to work and spread the disease by their contact with people (Al-Balatheri, 1956, p. 153). 
The followers and viewers of Omar Bin Al-Khattab's internal policy; from far distance find themselves at a contradiction in the understanding between the caliph's central and personal dealings method with the most accurate detail, and the absolute justice concept that was believed in and adopted by Omar, but understanding the political and historical context and course of Omar Bin Al-Khattab's succession justifies this method, which seemed to be a traditional or authoritarian management style. However, we believe that Omar Bin Al-Khattab has realized a brittleness and weakness in the new managerial and institutional system, and out of his devotion to make the experiment a success, he took the initiative personally by permanently supervising all its parts especially since the state has begun to expand rapidly through the Islamic conquests, which calls for the need to establish a solid ground for the new Islamic state, but we should acknowledge that Omar Bin Al-Khattab's successes in the management in terms of public affairs and the concept of social welfare far exceeded its failures.

Omar Bin Al-Khattab concept for the society welfare was manifested in the year of scarcity or "Al-Majaah" after people suffered from drought on the island, which led him to take many measures and procedures in order to aid people and save their lives; as much as possible by supplying the "Al-Araab" or Bedouins and Barbarians with the provisions, camels, wheat, and oil which were available at the surrounded villages and rural areas (Al-Albany, 1997, p. 211). One of his measures was to make appeal to his governors and leaders, where he ordered Moawiah Ibn Abo Sofian to send food from Damascus Al-Sham to the outskirts of Al-Jazeera from the side of Damascus and to divide it and distribute it to the people. He also ordered Saad Bin Abe Waqas to send food to the outskirts of Al-Jazeera from Al-Iraq side (Ibn Saad, 1997, c3, p. 236), but in regard to the issue of Omar requesting the help from Amro Bin Al-As from Egypt, these recitals or narrations can't be true due to the fact that Egypt wasn't opened at the time of "Al-Ramadeh" yet (Al-Jaidi, 2012, p. 252-254). In the year of "Al-Ramadeh" or "Al-Majaah" which is the year of scarcity, Omar was going out to the outskirts of Al-Medina city to check on the conditions of Bedouins people who escaped from "Al-Majaah" or starvation, get to know their situations, and seek to provide the relief for them. In this year of "Al-Ramadeh" many of the Bedouins people came to Al-Medina escaping from "Al-Majaah" or famine and droughts, especially since they were the most affected by it (Ibn Saad, 1997, c3, p. 240), therefore Omar directed all his capabilities, potentials, and possibilities to alleviate their suffering, and assigned for them men and workers who distributed and divided the food between those Bedouins who came to Al-Medina. The recitals or narrations mentioned that number of people who came to Al-Medina and lived at its outskirts or suburbs were nearly 50,000 people, and this number quickly increased to 60,000 individuals, and its worth mentioning that Omar was himself supervising and directing the preparation and distribution of food for them (Ibn Saad, 1997, c3, p. 240-241) where he was slaughtering the camels to prepare feasts and extensive meals for them (Al-Balatheri, 1996, c10, p. 395), and Omar was also supervising the process of cleaning and preparing the dead people, praying on them, and help in burying them. Its worth mentioning that "Al-Ramadeh" decimated and perished two thirds of the Bedouins people (Ibn Saad, 1997, c3, p. 241).

Caliph Omar was dedicated to send food to "Al-Araab" or the Bedouins people who couldn't come to the feasts that he prepared inside Al-Medina city, where he sent food and dates to their places of residence around Al-Medina to be enough for a month. After the drought end and the rain came, Omar Bin Al-Khattab supervised and hired people to supervise the return of the Bedouins people to their homelands carrying food and provisions (Ibn Saad, 1997, c3, p. 241), and Omar stopped taking Al-Zakat from people in the year of "Al-Ramadeh", and didn't send the official tax collectors to them until the end of "Al-Ramadeh" and after the things return to its normal state, only then he sent AlZakat workers where they took two amount of Zakat from them, one for the year of "Al-Ramadeh" and the other for the following year, and ordered the distribution of half of Al-Zakat between them and sent the other half to the Al-Medina city (Ibn Zanjaweah, 1986, c3, p. 1188).

Al-Caliph Omar's food and nutritional aid didn't stop after "Al-Ramadeh", but he designed warehouses to store food and provisions known as the house of flour where it were used to store the flour, "Al-Saweiq", dates, and raisins and made this house a place to help the fitful or broken people, the guests, and the newcomers to the city of Al-Medina (Ibn Saad, 1997, c3, p. 214) and he did slaughter a camel every day to feed and nourish people who came down to AlMedina from the Muslims and the poor people (Ibn Assaker, 1996, c44, p. 296), and he also put the water ways on the road between Mecca and Al-Medina (Ibn Saad, 1997, c3, p. 214). It's clear from these smart measures which Al-Caliph Omar bin Khattab used to manage the crisis and helped the state to overcome the year of "Al-Ramadeh" or "AlMajaah" and the period after it, but at the same time it indicates the adoption of Islamic State; at the time with the care of folks from different levels on the centralized work style or method, which is a sophisticated form for the concept of roles integration between the different parties to achieve the social welfare that is connected to the individuals' rights in their country. 
Second: State and the Social Welfare of Women: Woman at the time of Omar Bin Al-Khattab were appreciated for their position and their importance role in society, therefore he prescribed a grant or salary for her and made it an independent allowance from her husband (Abu Yusuf, p. 44-45) and even he did dispense the musk on them (Malek, 1994, c1, p. 516) which is one of the most beautiful perfumes, and its also an understanding of women' needs.

Al-Caliph Omar also worked to save and guard the society from all the reasons and sources of ethical and behavioral delinquency, and as a result he didn't leave any signs of social problem that may causes dangerous consequences on the society, its composition, and cohesion but sought to understand it, analyze it, and take the necessary steps to solve it once and for all. One of these problems was women grumbling and complaining about departing or parting from their husbands which may lead to the prevalence of obscenities in society, and while Omar was walking around in the AlMedina checking and looking over people's conditions, he heard a woman saying poetry and complaining about the absence of her husband, and that she missed him so much, who went out on the conquest or "Al-Fateh" movement, therefore Omar sought to understand the problem, determine its causes, and the way to solve it, so he asked his daughter, Um Al-Mu'mineen, Hafsa about the time period that woman could leave her husband and stay away from him, and she told him it was six months (Ibn Sheba, 1996, c1, p. 402-403). After that, Omar ordered that military outing shouldn't exceed a period of six months, and ordered that it return six months after its departure (Al-Sananni, 1970, c7, p. 152).

In order to preserve society, Omar urged Muslims to facilitate the marriage of their daughters by asking them to follow the example of the Prophet (PBUH) by staying away from the exaggeration and amplification in the dowry by saying: "Don't exaggerate at the dowries "Mohour" of women, where if it was a piety to God, then the daughters of the Prophet (PBUH) will be most deserving to it, where he didn't marry himself or marry others except for twelve ounces only" (Malek, 1985, c2, p. 575).

One of Omar's concern for women is that he didn't mistreat the punishment and tighten it on them, but he valued the circumstances and took the reasons into account to reduce their punishment, and when he heard that a young woman had killed her elder sheikh husband, he didn't take revenge from her and execute her but merely imprisoned her, then he went up the pulpit and addressed people alerting them from the consequences on society from such marriages and people who don't take into account the closeness of couples in age, appearance, and ability, and he said: "O people, fear God where one of you should marry a women who is similar to him in the (appearance and ideals)", stressing on the parity and equivalence between the spouses in the age, appearance, and body (Ibn Sheba, 1996, c1, p. 408). AlSha'ranni even quoted from Al-Bayhqy that Omar when a woman was brought to him who killed her husband, he asked her aiming to understand the circumstances and motives of the crime and she told him that her family forced her to marry from her elderly husband while she was very young, and that when she couldn't get rid of him, she killed him by beating him with a stone, and then Omer ordered the retribution to be executed and carried out on her, but he secretly asked his family for her to disappear or escape (Al-Sha'ranni, 1993, c1, p. 362). In order to prevent such events and crimes from happening, Omar urged people that women have the right to select the husband who she satisfied with his appearance, body, and age, and he called on parents to not force them to marry who they don't like, which may lead them to commit crimes and other things, and Omar Bin Al-Khattab was saying: "One of you go and force his daughter to marry the ugly husband, they love what you love" (Al-Sanaani, 1970, c6, p. 159), and he also was saying: "None of you force their daughter to marry the ugly man, they love what you love" (Ibn Sheba, 1996, c1, 408). Omar also didn't mind that woman should have an economic role and should take over her own business, where she will work in trade, and sells and buys by herself, and even he didn't mind to give her loans from the Muslim money house to trade in it. As an example, what Al-Tabari tells that Omar Bin Al-Khattab gave Hind Bent Otbah four dirhams from the money house as loans to trade in it and ensure its payment, where she went out with the money to the "Klab" land at Al-Sham or Damascus, she sold and bought, and then she visited her son Moawiah in Damascus, and then returned to Al-Medina with goods that she sold in it (Al-Tabari, 1977, c4, p. 221). This indicates that Omar's social policy was pushing toward preventing any injustice or danger from happening to women's lives.

Third: State and the social welfare of children and orphans: In the era of Omar, the state provided great care and nurturing for orphans, where he specified for them one day a week to look into their affairs and money (Al-Sanaani, 1970, c2, p. 349) and he did sell the vegetables and fruits of their crops (Al-Sanaani, 1970, c8, p. 66), and he also headed toward investing their money by giving the orphans' money he had to the traders for a speculation trade at sea (Ibn Abe Sheeba, 2006, c11, p. 161) and he urged people and motivate them to invest the orphans' money they have in the trade by saying, "Trade in orphans' money, and give their handouts, charity, and profits" (Al-Sanaani, 1970, c8, p. 68). Omar wanted through his inspiring and encouraging of people and traders to invest in the orphans' money to develop it, not to frozen it, and not to decrease it, as he always sought to assist and contribute to the orphans. 
Omar's awareness and realization for the importance of orphan care is an important part of his awareness of the state's responsibility towards this segment of population, which is one of the most vulnerable segment in the society and it shouldn't be persecuted, oppressed, or go toward the deviation. Omar Bin Al-Khattab gave the children special attention and took care of their education, where he assigned three teachers to educate the children of Al-Medina, and allocated for them a monthly donation or salary for their work (Ibn Abe Sheeba, 2006, c11, p. 28), and Omar imposed for the children of fighters, companions, and brothers a donation or aid (Ibn Zanjaweah, 1986, c2, p. 536) to provide their families with the money to pay for their expenses and needs, where initially he wasn't impose the donation on children except at the weaning (Malek, 1994, c2, p. 515-516), but later he changed his opinion and paid for them at birth (100) dirhams and two feasts of food a month; male or female and if they grew up increased it to (200) dirhams, and then if they becomes adults he offered more for them (Abu Yusuf, p. 46-47).

Omar Bin Al-Khattab never equaled between children and adults in punishment, and Omar did refuse to implement the laws or terms on children for an important and very fair argument, where he argued that if children don't reach the fullgrown age and understand the rules of religion then the laws, rules, and terms don't apply to them due to the lack of understanding of the religion and its rulings, and their poor perception of the consequences of what they did, and the seriousness of their actions (Al-Sanaani, 1970, c10, p. 179). This is very important in the awareness and recognition of social and individual responsibility, and in the early awareness of children's rights, and it's also an earlier expression of the concept of state care for juveniles and delinquents.

\section{Fourth: Poor and "Garimeen"(Insolvent or In Debt):}

Omar didn't only keen on one aspect of the Islamic society welfare, but he was dedicated to raise the level of the poor and those with economic needs, where he did give a full charity to the people of one house in order to prevent them from asking and change their economic situation, and he felt that its acceptable to give Al-Zakat in one category of people (Abu Yusuf, p. 81). He also ordered the charity workers to distribute Al-Zakat on the poor, and to start first with the helpless, the poor, and the needy of the Muslims by giving them an adequate charity and satisfy their needs of camels and sheep (Al-Sanaani, 1970, c4, p. 16-17). In order to help the poor in their livelihood, Omar headed to secure goods and products for them at reasonable prices by preventing the monopoly in the markets due to its significant effects on the high prices of goods and products, and he declared by saying: "Monopolist isn't permitted to sell in our market" (Al-Sanaani, 1970, c8, p. 206).

In order to confirm this matter, he declared his rejection to the practices of some merchants of Al-Medina who monopolize all goods and products, by buying it from its owners who come to the market to sell their goods, in order to sell it later in the market at the price they want, and to prevent this monopoly he invited the people who come to the market with their goods to take over selling their own goods, guaranteed for them the freedom to act, sell, and buy, and declared that they are under his protection, and that no one can expose himself on them (Al-Byhaky, 2003, c6, p. 50). He called on traders at Al-Medina to bring their goods from different countries, and told them they can do whatever they want with the exotic goods. Omar wanted to prevent monopoly, increase the commercial competitiveness, prevent high prices, expand the sources of goods, and prevent the speculation among sellers in the market, where they have to abide by the prices of the market, and when he found a man who wasn't selling at the market price, he ordered him to abide by the market price or leave, and when the man didn't comply with the price, Omar took him out of the market (Ibn Sheba, 1996, c1, p. 397-398). Omar also sought to help the insolvent or in debt from the "Garimeen", where he wrote to one of his workers about a group of "Garimeen" who had a due debts to the Muslim "Bayt Al-Mal" or money house, where apparently he ordered him to delay the payment of one third of their debt, relieve them from the other third, and ordered the worker to pay one third of what they had left from the "Bayt Al-Mal" or money house (Ibn Abe Sheeba, 2006, c11, p. 684).

\section{Analytical Summary}

The issue of social security derives its importance from the entrenchment and stabilization of social dimension at the social development system, and one of the most important elements of individual integration in the society and its adaptation or adjustment with its surrounding environment is his sense of social security, its a feeling that will drive the energies and aspirations of individuals to achieve more work, production, and upgrading. Omar Bin Al-Khattab seems to have understood this early and worked to embody this concept through the direct actions and procedures that he was taking towards different segments of the society. Therefore, we find that social welfare looks at the individual as a dynamic unit that grows and changes, while individual is in a state of interaction with other individuals, groups, local communities, or society in general. 
This interaction consider necessary for the growth of individual psychologically, socially, economically, and politically, and that each individual who interacts with other units is in need of the presence of others to be able to achieve the goals and satisfy the needs (Sumayah Abdul-Al-Qadir, 2008).

The belonging to the group make the individual feels strong, but this feeling must be mutual between the individual and the community, which is the matter that Omar Bin Al-Khattab expressed about the need of community and society to take care of all those who need help. The concept of social security consider an expression of a set of measures and procedures which aimed to protect the society from all risks, and its also a set of actions, programs, and plans which aimed to provide the comprehensive guarantees that surround each individual in the society with the necessary care and welfare, and provide the individual with ways to achieve the development of his capabilities and possibilities, and the highest self-sufficiency within a limits of freedom and justice (Michael Man, 2003). The succession of Omar Bin AlKhattab came with important civilized results, which through it the Islamic State expressed the beginning of social welfare concept system that included all marginal and fragile segments of women, children, and the poor, and it also expressed a social policy for the state concept and its responsibilities towards its citizens.

\section{References, Sources, Articles \& Researches}

Al-Albany, Muhammad (1997), "True Singular Literature for Al-Imam Al-Bukhari", I4, Al-Daleal Library, Saudi Arabia

Abdul-Al-Qadir, Sumayah Suleiman (2008), "The Development of Social Welfare Values at the Humanitarian Society", $21^{\text {st }}$ International Scientific Conference for Social Service, Volume 14, Faculty of Social Service, Helwan University

Abu Yusuf, Yacoub Bin Ibrahim, "Al-Kharaj", Dar Al-Marefah, Beirut

Al-Balatheri, Ahmed Bin Yahiya (1996), "Gentlefolk Descent", I1, Edited by Sohial Zakhar, Raid Zarkali, Dar Al-Fikr, Beirut

Al-Balatheri, Ahmed Bin Yahiya (1956), "The Conquest of Countries", Published and developed by Salah Al-Dean AlMunjjid, Egyptian Renaissance Library, Cairo

Al-Byhaky, Ahmed Bin Al-Hussein (2003), "The Big Sinan", I3, Edited by Mohammed Abdelkader Atta, Scientific Book House, Beirut

Al-Jaidi, Shalabi Ibrahim (2012), "Al-Ramadeh Year, an Analytical Study", the Scientific Journal of Faculty of Arts, P2, Faculty of Arts, Dumyat University

Al-Sanaani, Abdul Al-Razzaq Bin Hammam (1970), The Classifier or Al-Musanaf, I1, Edited by Habib Al-Rahman Al-Azami, Scientific Council, Beirut

Al-Sha'ranni, Abdul Al-Wahab (1993), "The Lawaqeh of Al-Anwar Al-Qudsiah in Bayan of Al-Ohood AlMuhammadiah", Presented by Muhammad Ali Al-Adlabi, Dar Al-Qalam Al-Arabi, Aleppo, Syria

Al-Tabari, Mohammed bin Jarir (1977), "The History of Apostles and Kings", Edited by Muhammad Abu Al-Fadil Ibrahim, Dar Al-Ma'aref, Cairo

Gooby, Peter Taylor (1991), "Social change, social welfare, and social science", N.Y., Harvester wheat sheaf

Ibn Abby Al-Dunya, Abdullah Bin Mohammed (1986), "Money Reform", Edited by Mustafa Al-Iqtha, Dar Al-Wafaa for Printing and Publishing, Mansoura

Ibn Abe Sheeba, Abdullah Bin Mohammed (2006), "The Classifier or Al-Musanaf" I1, Edited by Mohammed Awamah, Dar Cordoba, Beirut

Ibn Assaker, Ali Bin Al-Hassan (1996), "History of Damascus", I1, Edited by Omar Bin Aramah Al-Amouri, Dar alFikr, Beirut

Ibn Saad, Mohammed Bin Saad (1997), "The Big Classes", I2, Edited by Mohammed Abdelkader Atta, Scientific Book House, Beirut

Ibn Sheba, Omar Bin Sheba (1996), "History of Al-Medina Al-Munawareh", Edited by Ali Dandal, Yaseen Bayan, Scientific Books House, Beirut

Ibn Zanjaweah, Hameed Bin Mukhlad (1986), "Money", Edited by Shaker Deeb Fayyad, King Faisal Center for Research and Islamic Studies, Riyadh

Khalil, Mona \& Attia, Khazam (2010), "Social Safety Network and the Improvement of Poor Life Quality", Modern University Office, Alexandria

Malek Bin Anas (1985), Al-Mowata, Corrected by Mohamed Fouad Abdel Al-Baki, Arab Heritage Revival House, Beirut

Malek Bin Anas (1994), "The Big Record or Modawneh", I1, Scientific Books House, Beirut

Michael, Man (2003), "Encyclopedia of social science", London, $4^{\text {th }} \mathrm{Ed}$ 